\title{
ANALYSIS OF INDUSTRY PERCEPTIONS AND EXPECTATIONS OF TOURISM STUDENTS: A CASE STUDY IN TURKEY
}

\author{
Fatma Gül TURANLIGÍL \\ Freelance Academician, Izmir, Turkey \\ e-mail: fcetinelakalin@gmail.com \\ Volkan ALTINTAS \\ Izmir Katip Celebi University, Faculty of Tourism, Izmir, \\ Turkey, e-mail: volkan_altintas@hotmail.com
}

\begin{abstract}
Citation: Turanligil, F., G., \& Altintaş, V., (2018). ANALYSIS OF INDUSTRY PERCEPTIONS AND EXPECTATIONS OF TOURISM STUDENTS: A CASE STUDY IN TURKEY. GeoJournal of Tourism and Geosites, 21(1), 266-281. https://doi.org/10.30892/gtg.21121-286
\end{abstract}

\begin{abstract}
Tourism and Hospitality Management Schools' students must complete their internship before graduation in four or five stars hotels or travel agencies in Turkey. Some students may have negative perceptions of tourism education and working conditions in the industry, after they have worked as trainees in the industry. The aim of the study is to compare the perceptions and expectations of students in relation to tourism industry who have done their internship with those who have not and is to explore the differences in their future expectations and any changes in their career plans. For the purpose of the study a questionnaire was prepared, based on relevant literature, and the survey was conducted in the School of Tourism and Hotel Management at Anadolu University in Turkey. 204 students were selected by the use of stratified sampling as the study sample from the first, second, third and the fourth year. Half of the questionnaires were distributed to students who had done their internship and the rest to the students who had not undertaken internship yet. Results indicate that the respondents' perceptions and expectations of the industry were not significant according to their experience. Finally, the differences between respondents are summarized and implications are drawn for the educational institutions and further studies.
\end{abstract}

Key words: Tourism education, tourism students, internship, student's perceptions

\section{INTRODUCTION}

By its very nature, tourism is a labour-intensive service industry. The growth of tourism and related employment is seen as part of the broad shift from a manufacturing to a service economy in many developed and developing countries around the world (Roney \& Öztin, 2007). Most services in tourism are based on human (employee) performance,

\footnotetext{
* Corresponding author
} 
services are produced and consumed simultaneously in a face-to-face exchange situation and employees and customers are physically and psychologically close enough to influence each other (Kusluvan \& Kusluvan, 2000). The success of the hotel industry heavily depends on the social and technical skills of its personnel, their ingenuity and hard work, their commitment and attitude (Nolan, 2002). Employee attitudes, performance and behaviour are a key determinant of service quality, customer satisfaction and loyalty (Heskett et al., 1994). Although people in many countries are encouraged to regard tourism as a very large industry with huge opportunities for jobs and careers (Leiper, 1999), tourism industry is often criticised as generating low-skilled and low-paying jobs that offer little job satisfaction. Market entry barriers for non-tourism trained employees are low (Peters, 2005) and consequently, the tourism industry has a reputation for high staff turnover and a waste of trained personnel (Roney \& Öztin, 2007). Since competitive advantage is gained through employees, the education, skills, training and motivations of employees as well as their commitment to the industry or firms become important. Besides other problems, the most important problem appeared to be the continuous supply and retention of a well-educated, well-trained, skilled, enthusiastic and committed work-force for the tourism industry (Kusluvan \& Kusluvan, 2000).

A professional competitive industry attempting to deliver international standards of service depends on the subsequent education and training of such personnel (O’Mahony \& Sillitoe, 2001). Since the continued prosperity of tourism depends, to a large extent, on the employment of well educated, motivated and committed people, who are satisfied with their jobs, it is important to provide qualified tourism students with a positive attitude towards work in the tourism industry (Roney \& Öztin, 2007). In the service industries, without employees' positive attitude toward their jobs, it is impossible to achieve customer satisfaction and loyalty. Besides the negative perceptions of industry, career opportunities have been shown to prevent talented individuals to entry into the industry's workforce (Pizam \& Tesone, 2005). If today's students are to become the effective practitioners of tomorrow, it is fundamental to understand their perceptions of tourism employment (Roney \& Öztin, 2007). The aim of the study is to analyze the perceptions and future expectations of bachelors students about tourism industry. It also aims to compare the perceptions and expectations of students who have done their internship and with those who have not and, to find out the differences in their future expectations and any changes in their career plans. For the purpose of the study, tourism education literature was reviewed and the study results were analyzed.

\section{Tourism education}

The boom in tourism education came after the birth of mass tourism, and the rapidly increasing demand for employees in the tourism industry during the decades following the Second World War. Another vital factor in the increasing importance of tourism education was the growing international recognition of the value of the tourism industry (Munar, 2007). In 1960s, several key changes in tourism, in higher education and in society. One outcome of this change in tourism has been a phenomenal rate of growth. This growth, combined with the increasing professionalization of the tourism suppliers, has played its part in prompting educational institutions to meet the demands and opportunities created by tourism employers. Also, this level of tourism growth has brought with it a complex array of issues from economic benefits to social and environmental problems. These challenges presented by tourism have enhanced the sustained interest by scholars, particularly in higher education, in their attempts to understand and explain aspects of an important worldwide phenomenon (Airey, 2005).

The development of tourism in higher education was not accidental. Airey (2005) has identified three growth factors that lie behind the emergence of tourism after the mid- 
1960s. The first was the growth of tourism itself and its recognition, especially by governments, as an increasingly important economic activity. The second was the growth of higher education generally as the link between an educated workforce and economic development was increasingly recognised. Linked to this, the third factor was the creation of new universities. These, free from the traditions of the older universities, provided homes for new and often more vocational areas of study. With its potential to attract new students, tourism proved popular programme to include in the offerings of the new universities. The result was a huge increase in the numbers of programmes, students and subsequently the research and literature related to tourism (Airey, 2016). A number of key changes in tourism, in higher education and in society were needed for tourism to become established as a defined area of study and as a subject for study to diploma and degree level. Degrees developed in higher education institutions first in Europe, later in the United States and Canada, and then Australia and New Zealand (Jenkins, 1997 cited in Munar, 2007). During the last three decades there has been a steady increase in the number of universities offering tourism and/or hospitality degree programmes, especially after the 1980 (Jafari, 1997 cited in Munar, 2007). At the beginning of twentieth century, many countries offered higher education degrees in tourism at both undergraduate and graduate levels; and master-level degrees and doctoral programmes in other disciplines have expanded to include tourism as an area of study (Jafari, 1990). Studies concerned with the global expansion in tourism education identified three main responsible drivers of this phenomenon: a set of structural changes in higher education in general (Ayres, 2006), a perceived need of increasing qualified human resources for tourism industry, and a common perception of tourism as a major source of jobs and careers (Padurean \& Maggi, 2014).

Gaining competitive advantage through employees who provide better service quality, and making the customers happy and loyal in the tourism industry and firms depends on the supply and retention of educated, well trained, skilled, highly motivated and committed work-force for the travel and tourism industry (Christou, 1999). Tourism education accomplish an important mission in terms of supporting the improvement of tourism and providing quality human resources permanently (Akincı, 2016) and it has been developed to balance the tourism development demand for fulfilling the broader perspective of managing tourism. The industry needs more comprehensive analysis than just providing the skilled graduates to be able to work in the tourism business (Malihah \& Diyah Setiyorini, 2014). As the tourism industry evolved, tourism educators started to redefine tourism education to include the skills necessary for employability in the industry (Jameson-Charles, 2012).

The responsibility for developing service-oriented human resources regards not only with the hospitality organisations but also with the system of a country's hospitality management education and an effective hospitality education system will provide organisations with employees who have the potential to become quality leaders. The role of hospitality educational institutions must be to produce graduates who can think, lead, and solve problems (Christou, 1999). Directly, the role of institutions of higher education is to recruit and educate potential hospitality managers (Barron \& Maxwell, 1993). Christou \& Sigala (2002)'s research findings provided emprical evidence of the, to some extent overlooked, need to take into consideration the characteristics and needs of hospitality students in designing and developing hospitality educational material, learning methods and teaching environment. The responsibility of the hospitality educators according to Stutts (1995) is to combine industry priorities with student needs and significant contributions to research into socially responsive programmes of study. Ongoing partnerships between higher education institutions and the tourism sector at all levels are needed to transfer knowledge into practical use (Hawkins, 2006). In addition, 
tertiary hospitality education should assist the student to develop communications and interpersonal "soft" skills and learn how to lead others (Goodman \& Sprague, 1991). The development of students' interpersonal skills is considered to be very important according to views of the hospitality industry (Tas, 1988). A common distinction between education and training is that education is mainly provided by establishments like universities while training is usually provided by employers (organisations). The education and training of professionals, in whatever discipline, is a continuing and lifelong process. Therefore, it is not realistic to impose an absolute distinction between education and training because they are not exactly two independent processes. Both the educational establishments and employers seriously need to consider this development of lifelong learning. The most popular of the experiential learning models are the internships (Christou, 1999). It is suggested that some skills are essential for employment and, arguably, the internship is the most appropriate vehicle for their acquisition. Certainly, for the development of practical skills, the internship is crucial (Busby, 2003). However, research on internship programs has shown significant gaps in expectations between industry and hospitality educators (Downey \& De Veau, 1988).

Internship programmes are academic programmes that encourage students to apply theory in work settings and gain greater work competencies. Furthermore, students might be able to evaluate their professional growth based on the results of their work experience. The authors argue that if organisations recognise students' needs and wants and support their enquiries during an internship, students will more effectively and efficiently learn and work (Kim, 2008). Student interns are expected to try their best to obtain the employment-required techniques, knowledge, and interpersonal relationship in order to get a better job after graduation. Since real work environment is taken as a part of school learning, students are able to get a practical understanding of the condition and development of their future work from daily work experiences and observations (Lee et al., 2006). Internship programs provide students with needed tools and educate them to take responsibility in their future work life. They felt that the faculty should assist them and became bridges between students and industry professionals (Ko, 2008). One common form of experiential learning in tourism and hospitality management is the internship programme (Austin \& Rust, 2015). Internship students learn to make connections between what they are learning in their courses and their training experiences. Internships provide opportunity for students to decide if their previous career choice is appropriate for their passions and personalities. Without industry experience, they have troubles in understanding how all elements of the operation and all courses, form an integrated whole (Başaran, 2016). On the other hand, if organisations give students the opportunity to experience several departments during their internship programme, they will concentrate more on their study and they will be better prepared for higher-level positions (Kim, 2008). Through internships students have more chances to explore future careers, to gain deeper knowledge of details, and to start thinking about their future careers based on their internship experiences. If the students do not have successful internship experiences, they are less likely to consider the hospitality industry for possible future careers (Ko, 2008).

As a result, hospitality companies will also benefit. Hospitality companies may be better able to hold their employees and encourage high performance (Kim, 2008). Internship not only provides them with technicians of high quality on production lines, but also enables them to employ students with work experiences as perpetual employees. Also, internship, employers can hold knowledge and technique trainings fit for their companies (Lee et al., 2006). Most of industry professionals agree that hospitality students who participate in internship programs are more marketable (Ko, 2008). 


\section{Tourism education in Turkey}

Tourism education in Turkey has started with the vocational tourism courses opened in Ankara and Izmir Business High School, in 1953 and developed by tour guidance and interpreting courses in some tourism related associations. Following, tour guidance courses were opened in Istanbul in 1955. Tourism was accepted as a scientific specialty in 1960 by the regulation on the Law on Academia of Economic and Business Sciences. As in the same manner, establishment of Ankara Hospitality School in 1961 and previous efforts are all improvements realized prior to planned period (Boylu, 2002).The supreme authority for the regulation of higher education is the Council of Higher Education (YÖK), which comprises a fully autonomous national board of trustees. There are three other upper administrative bodies in the field of higher education: The Inter University Council (UAK), the Turkish University Rectors' Committee (TURC), and the Higher Education Supervisory Board. The Turkish higher education system has a centralized structure. All universities (both state and private, or in a true sense, foundation universities) are subject to the same laws and regulations/rules. The universities are founded by law; and their affiliated faculties, institutes, and four-year vocational/professional high schools are founded by a decision of the Parliament; while the two-year vocational high schools and the departments affiliated to the universities are established by YÖK. The opening of a program at any level needs to be approved by YÖK (Okumus \& Yagci, 2005) and it is responsible for the implementation, organization and coordination of these. The Ministry of Culture and Tourism, TUREM (Tourism Education Center), and MEB (Ministry of Education) organize and implement diffused education, while the Council of Higher Education (YOK) is responsible for the higher tourism education system (Çakar \& Çizel, 2015).

Tourism education in Turkey is carried out in two ways as formal and informal. Educational institutions providing formal education consist of schools offering vocational tourism education at secondary and tertiary level. Informal tourism education includes short-term vocational courses offered by both official and private institutions. Vocational tourism education offered in secondary schools providing formal tourism education (Akınci et al., 2017) and those schools termed the Anatolian Hotel and Tourism Vocational School, which is organized and coordinated by the MEB. These vocational schools offer tourism education at a basic level and include learning a foreign language. Overall, the length of the period of education at the Anatolian Hotel and Tourism Vocational Schools is four years. The first year consists of preparatory classes in which the students are obliged to learn a foreign language. The remaining three years provide these students with an education in tourism which is combined with practical work experience within the tourism industry. According to the National Education Statistics for the educational year 2013/14, the number of Anatolian Vocational High Schools for Hotel Management and Tourism consisted of 135 (Çakar \& Çizel, 2015). Associate degree education is provided for two years at higher education institutions and students are placed according to their diploma grades from the secondary schools providing vocational tourism education in Turkey, primarily from district schools among the secondary schools where tourism education is offered without examination. Undergraduate degree education at higher education institutions covers a total of four years, including eight semesters. According to the central examination system, these institutions admit students from all secondary schools. It is getting very difficult for students studying in secondary schools that provide tourism education based on the vocational curriculum to get a place in schools providing 4 years of undergraduate degree tourism education due to the central examination system (Akıncı et al., 2017). In addition, additional higher level educational opportunities are offered in the form of a two-year master program and a three-year $\mathrm{PhD}$ program. In some universities, the duration of the $\mathrm{PhD}$ is four years, rather than the three 
years in the field of tourism management. There are 37 programs at the master level and 17 programs at the $\mathrm{PhD}$ level that currently offer at postgraduate level tourism education in Turkey (Çakar \& Çizel, 2015). Anadolu University also offers two- and four-year programs through distance education (Okumus \& Yagci, 2005).

\section{Industry perceptions, career expectations and employment positions after graduation}

If an educational institution does not determine the expectation level of its students, it is also impossible for it to identify exactly why their perceptions and expectations do not match. Determining the relation between the pre-formed expectations of the students who come to school to receive tourism education, their perceptions occurring through experience, and satisfaction emerging after perception is of great importance in terms of schools aiming to offer sustainable quality tourism education. For the perception of tourism education that is offered to be high, firstly there should be efforts to make the conscious students who have a high level of expectation from tourism education and information about tourism sector for various reasons (like having a career in tourism sector) to prefer the school (Akıncı, 2016). If graduates know and understand employment conditions prevailing in the hospitality industry, they will have realistic expectations of what work entails (Sibanyoni et al., 2015). Students of hospitality management tended to have high ambitions for their future working career when they began their studies, but their ambitions changed after recognising the actual circumstances of the industry. As a result, some students tended to change their goal, which has serious implications for students, education providers, and the hospitality industry. For example, if many people view the working environment of the hospitality industry negatively, then potential students may choose not to study hospitality and education providers will find it difficult to recruit students and provide high quality courses. Furthermore, the hospitality industry will find it difficult to select employees who have good quality qualifications, which also will affect customers (Kim, 2008).

Previous literature on the students focuses on: industry perceptions of students; their career expectations; and, employment positions after graduation. Barron and Maxwell (1993) conducted a survey at Scottish universities to determine the beliefs and thoughts, and perceptions of students related to tourism industry. In their study, it is evident that new students generally hold positive views, whereas the more experienced students generally hold negative views; demonstrably there is a disparity between students' expectations and experience of the industry. Similarly, in their survey held in three universities with tourism programmes in Turkey, Roney and Öztin (2007, p.13) concluded that: "even if new students start with a more optimistic view of the industry, after the internship period and (for some students) part-time work experience, they develop a less favourable perception”. Results of Kozak and Kizllırmak (2001)'s survey have indicated that having an internship in the industry was an important determinant on the students' industry-related attitudes. The results of Aksu and Köksal (2005)'s study generally show negative perceptions and attitudes towards the tourism industry, but some positive perceptions and attitudes are also emerged. The negative impressions resulting from placement experiences identified in KelleyPatterson, and George (2001)'s study, suggest that the image of the sector is seriously damaged in the eyes of many potential employees. Students can be regarded as the future employees of the tourism and hospitality industry so it is inevitable to understand their employment intentions. Some surveys show that students and graduates of tourism and hospitality programs have little or no intention of entering the industry upon graduation (King et al., 2003). While tourism sector is encouraging many people to join the sector with its wide job and career opportunuties, on the other hand it is a sector that majority of the people who studied or still studying tourism are not willing to work in (Yllmazdogan et al., 
2015). If hospitality graduates are entering the industry without an accurate understanding of the industry, this could be the cause of many leaving the hospitality industry. A disparity between what employees' prospect and what they experience has been suggested as one of the reasons hospitality employees leave the industry (Blomme et al., 2009). It is important to determine where gaps exist so educators and practitioners can make a difference (Anandhwanlert \& Wattanasan, 2016).

To attract and retain talents in the tourism and hospitality industry, career expectations of graduates need to be better understood. In any event, understanding and meeting workers' career expectations is an important step in recruiting, retaining and motivating young employees (Grobelna, 2017). Wellings and Bibbings (2004)'s study aims to identify the motivations, perceptions and expectations of tourism undergraduates in relation to their programme of study, the student experience, and future career prospects. The majority of respondents have some relevant prior work experience. In all subjects this was predominantly in the hospitality sector (restaurants, hotels and bars) but also in public sector tourism, holiday parks, leisure centres, travel agents, events management etc. Most respondents enjoyed their experience of working in the industry, and in many cases, this inspired them to take on a higher-level qualification to increase their prospects of higher level management careers. In a survey on English and Dutch hospitality students, Jenkins (2001) found that as their degree progressed, the students' perception of the industry deteriorated and the desire to work there was diminished considerably, less than half of the students intending to enter the sector. Kusluvan and Kusluvan (2000)'s study revealed that there was not a strong commitment to the tourism industry among undergraduate students. Casado (1992)'s study can be given as an example of analyses on the students' career expectations following graduation and their intention to work in the industry. The results of this survey show that these students have fairly realistic expectations before they graduate.

Ross (1994) found that most respondents were highly interested in employment and perhaps a career in the tourism/hospitality industry. Airey and Frontistis (1997) have examined the attitudes of UK and Greek students towards tourism careers. Although the differences between the students in the two countries are less pronounced, these tend to confirm the generally more favourable attitude of the Greek students toward tourism and tourism careers. Pavesic and Brymer (1990) found that after about three years of work in the industry, a substantial number of these graduates have moved to another occupation. Their statistics showed a jump in the third year after graduation in the number of persons reporting that they were out of the industry. Purcell and Quinn (1996)'s research suggest that there are substantial overlaps in the motivations and orientations of diplomates and graduates, but their responses have a distinct tendency to polarize, especially with reference to the reasons they provide for studying hospitality and for entering the hospitality industry. Negative perceptions of industry career opportunities have been shown to prevent talented individuals from entering the industry's workforce (Pizam \& Tesone, 2005).

Tourism schools also have an important effect on the formation of students' career expectations and perceptions of the industry. Ayres (2006)'s study indicates that higher education is becoming increasingly important for employees in the tourism industry. Participants in the study endorsed the value of higher education for employees, but suggested the acquisition of more generalised skills and knowledge, rather than a narrow specialisation. The findings of this study suggest a close link between career development strategies and education. Garavan and Morley (1997) suggest that universities are vital in "structuring the experiences of graduates in terms of the kind of work they can expect to perform, their pay and promotion prospects and degree of freedom and discretion they 
may have within an organization." It is alarming to note that education may actually discourage hospitality graduates from entering the industry, as highlighted by Jenkins (2001). Industry has charged educationalists with producing poorly prepared graduates with unrealistic expectations, while educationalists have accused hospitality employers of outdated approaches towards recruitment and management in general (O'Leary \& Deegan, 2005). Critically, work experience appears to be the key source of this disenchantment with the industry. Previous studies have found that hospitality students are much less committed to the hospitality industry when they have more experience within the profession (Purcell \& Quinn, 1996; Getz, 1994). Researches revealed that important part of students who take tourism education after a while start to work in a sector, not prefer to work in the tourism industry (Menemenci Bahcelerli \& Sucuoglu, 2015). Research has also shown that internship experience negatively affects the hospitality students' attitudes toward the industry and their intentions in terms of getting hospitality jobs (Anandhwanlert \& Wattanasan, 2016). Many students recognise that they work just like front line employees during the whole period of their internship programme.Students might feel that organisations treat students as a source of cheap labour. Students expect that an internship offer opportunities to participate in meetings with managers and the opportunity to learn more specific management skills.

Therefore, students might be unsatisfied with their experience of internship. Experience from the internship will be a significant factor for students in making decisions about whether they want to work in the hospitality industry or not (Kim, 2008). Students who had positive attitudes towards their internship experiences and training had greater job satisfaction and confidence once in a career (Brown et al., 2014). Richardson (2008) found hospitality and tourism students who experience the hospitality and tourism industries, such as through an internship, are less likely to enter their respective industries. The hospitality graduates who stayed in the industry indicated they continued to remain in the industry due to the experiences, challenges, enjoyment, and to use their degrees. Perhaps with a balance between diverse internship experiences and career specific courses, students will be adequately prepared to enter the hospitality industry with more accurate expectations (Brown et al., 2014).

\section{METHODOLOGY}

The aim of the study is to determine students' perceptions regarding tourism industry and analyse their perceptions according to their internship experiences. The study population is composed of all students in the academic year of 2007-2008, in the School of Tourism and Hotel Management at Anadolu University, Turkey. 204 bachelor students were selected by using stratified sampling as the study sample from the first, second, third and the fourth year. Questionnaire was distributed in October 2007. All the questionnaires were collected and the results then analyzed. The questionnaire form was developed on the basis of previous studies (Roney \& Öztin, 2007; Aksu \& Köksal, 2005; Kozak \& Kizılırmak, 2001; Birdir, 2002). The questionnaire form included two sections. In the first section demographics of the students were questioned; the second section contained a set of 24 statements about the students' industry perceptions. A 5-point Likert Scale (strongly agree $=5$, agree $=4$, neither agree nor disagree $=3$, disagree $=2$, strongly disagree=1) was used to measure the students' degree of agreement or disagreement with various statements about tourism industry perceptions.

The questionnaire form was first distributed to 30 students and a reliability test was conducted on the pilot survey (Cronbach's alpha) and the reliability was calculated to be $73 \%$. Besides, the number of statements in the second section of the questionnaire was reduced from 29 to 24 according to students' feedback. 


\section{FINDINGS}

\section{Profiles of Respondents}

Table 1 depicts the profiles of the respondents. $67.6 \%$ of the respondents are male, and $32.4 \%$ are female. Respondents are mostly (63.7 \%) between 21-23 years old. $38.2 \%$ of the students were in the first, $21.1 \%$ were in the second, $23.5 \%$ in the third and $17.2 \%$ were in the fourth classes in the academic year of 2007-2008. 25.5\% of the respondents were graduated from vocational tourism high schools.

Table 1: Profiles of the student

\begin{tabular}{|c|c|c|}
\hline & Frequency & Percent \\
\hline \multicolumn{3}{|l|}{ Gender } \\
\hline Male & 138 & 67.6 \\
\hline Female & 66 & 32.4 \\
\hline \multicolumn{3}{|l|}{ Ages } \\
\hline Between 18-20 & 57 & 28.4 \\
\hline Between 21-23 & 128 & 63.7 \\
\hline Between 24-27 & 16 & 8 \\
\hline \multicolumn{3}{|l|}{ Class of the students } \\
\hline First class & 78 & 38.2 \\
\hline Second class & 43 & 21.1 \\
\hline Third class & 48 & 23.5 \\
\hline Fourth class & 35 & 17.2 \\
\hline \multicolumn{3}{|l|}{ The high schools they were graduated from } \\
\hline High school & 74 & 36.3 \\
\hline Vocational high school & 7 & 3.4 \\
\hline Vocational tourism school & 52 & 25.5 \\
\hline Colleges (High Schools where the focus is to educate students in foreign languages) & 42 & 20.6 \\
\hline Other & 29 & 14.2 \\
\hline \multicolumn{3}{|l|}{ Their willingness to study tourism at the university } \\
\hline Yes & 138 & 68.0 \\
\hline No & 65 & 32.0 \\
\hline \multicolumn{3}{|l|}{ Internship experience in the industry } \\
\hline Yes & 107 & 52.5 \\
\hline No & 97 & 47.5 \\
\hline \multicolumn{3}{|l|}{ Tourism businesses where students have internship } \\
\hline Hotels & 84 & 79.2 \\
\hline Holiday village & 9 & 8.5 \\
\hline Travel agency/Tour Operator & 10 & 9.4 \\
\hline F\&B outlets & 2 & 1.9 \\
\hline Other & 1 & 0.9 \\
\hline
\end{tabular}

The students who graduated from vocational tourism high schools had the chance to have an internship in their high school days, so they entered to higher education institutions with certain experience and perceptions. However, since most of the respondents have indicated that they graduated from other high schools, their industry perceptions were structured during their university years. $68 \%$ of the respondents have indicated that they willingly chose to study tourism. From the respondents, $52.5 \%$ had participated to an internship in the industry. And they mostly had their internship at hotels (79.2 \%).

\section{Students' Perceptions towards Tourism Industry}

Table 2 shows details of the degrees of agreement with each one of the 24 statements provided in the second part of the questionnaire. For simplicity, perceptions are summarised in group percentages as "strongly agree and agree" and "strongly disagree and disagree". 
Table 2: Perceptions of students concerning tourism industry

\begin{tabular}{|c|c|c|c|c|c|}
\hline Degree of agreement or disagreement with each statemen & 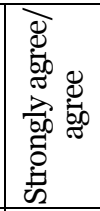 & 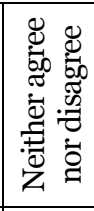 & 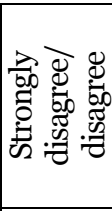 & 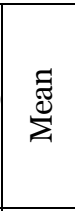 & 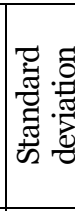 \\
\hline $\begin{array}{l}\text { 1. Bosses who are not educated or trained in tourism prefer unskilled, } \\
\text { low-paid employees for the purpose of making much profit. }\end{array}$ & \%91.1 & \%6.0 & $\% 3.0$ & 4.48 & .80 \\
\hline $\begin{array}{l}\text { 2. Participation of unskilled and non-educated people in the } \\
\text { industry diminishes job opportunities. }\end{array}$ & \%90.7 & $\% 4.9$ & $\% 4.4$ & 4.47 & .82 \\
\hline 3. An internship is necessary to work in the industry. & $\% 82.2$ & $\% 8.4$ & $\% 9.4$ & 4.19 & 1.03 \\
\hline 4. Working hours in tourism are very long and irregu & $\% 77$ & $\% 14.2$ & $\% 8.9$ & 4.06 & 1.00 \\
\hline 5. Wage levels in the industry & $\% 74.7$ & $\% 17.8$ & $\% 7.4$ & 4.06 & .93 \\
\hline 6. There is no job & $\% 71.5$ & $\% 19.6$ & $\% 8.9$ & 4.00 & 1.02 \\
\hline $\begin{array}{l}\text { 7. Bosses who are unaware about the indust } \\
\text { employ educated and trained, quality persor }\end{array}$ & $\% 69.3$ & \%21.8 & $\% 8.9$ & 3.96 & 1.05 \\
\hline 8. Tourism graduates were not considered. & $\% 74$ & $\% 14.7$ & $\% 11.2$ & 3.93 & 1.05 \\
\hline $\begin{array}{l}\text { 9. A regular remuneration is difficult to gain because of the } \\
\text { seasonality of the industry. }\end{array}$ & \%71.4 & \%17.7 & \%10.9 & 3.92 & 1.01 \\
\hline $\begin{array}{l}\text { 10. It is necessary to have a university degree to work in the } \\
\text { tourism industry. }\end{array}$ & $\% 69.4$ & $\% 10.8$ & \%19.7 & 3.90 & 1.28 \\
\hline 11. Owner/managers are not conscious about tourism. & $\% 66.8$ & \%26.2 & $\% 6.9$ & 3.89 & .92 \\
\hline 12. Working conditions in the industry affects the private life negatively. & \%71.1 & \%14.2 & \%14.8 & 3.85 & 1.07 \\
\hline 13. Personnel in the industry are not appreciated much. & \%68.1 & \%21.6 & $\% 10.3$ & 3.85 & .97 \\
\hline 14. There is no future warranty in tourism. & $\% 56.9$ & \%18.3 & \%24.7 & 3.54 & 1.31 \\
\hline rking in tourism suits me much. & $\% 49.5$ & $\% 33.7$ & \%16.8 & 3.47 & 1.18 \\
\hline 16. Career development in tourism is very slow. & $\% 51.2$ & $\% 27.4$ & \%21.4 & 3.45 & 1.10 \\
\hline 17. Career development in tourism is un-planned. & $\% 49.7$ & $\% 29.9$ & $\% 20.4$ & 3.42 & 1.07 \\
\hline $\begin{array}{l}\text { 18. The advantages of working in the tourism industry are much } \\
\text { more than its disadvantages. }\end{array}$ & $\% 35.4$ & $\% 39.9$ & $\% 24.6$ & 3.18 & 1.02 \\
\hline $\begin{array}{l}\text { 19. Since un-planned structure of the industry endangers the future } \\
\text { of the industry, I do not foresee a future for myself in this industry. }\end{array}$ & 3.5 & $\% 35$ & \%31.5 & 3.11 & 1.24 \\
\hline 20. There is gender discrimination in tourism. & $\% 37$ & $\% 24.5$ & $\% 38.5$ & 3.03 & 1.24 \\
\hline 21. I do 1 & $\% 26.8$ & $\% 30.7$ & $\% 42.6$ & 2.76 & 1.30 \\
\hline 22. Prom & $\% 19.8$ & $\% 41.6$ & $\% 38.6$ & 2.76 & .96 \\
\hline 23. Tour & $\% 18.2$ & $\% 38.4$ & $\% 43.4$ & 2.67 & .96 \\
\hline 24. I do not think that I would be patient and smile to the tour & $\% 11.9$ & \%11.4 & $\% 76.7$ & 1.94 & 1.10 \\
\hline
\end{tabular}

The majority of the respondents (91.1\%) believe that the bosses in the industry did not know the industry well and they mostly focused on the profits. Instead they prefer to employ unskilled, low-paid employees. The investment incentives in the late ' 80 os led investors who are not aware of the confines of the industry invested in tourism. $90.7 \%$ of the students think that the employment of people not educated in tourism diminishes the job opportunities for themselves. Their answers to this statement have resemblance with the previous statement. Because the employers prefer to employ low-skilled, low-paid employees instead of employing educated, probably much demanding employees. It is seen that $82.2 \%$ of the respondents have understood the importance of the internship in the industry. It is encouraging to find that $76.7 \%$ of the students expressed their disagreement with the statement of "I do not think that I would be patient and smile to tourists". This finding is interpreted as the students understanding of the industry, and being tolerant for the customer satisfaction. Students disagree with the statements of "Tourism related jobs are more respected than the other jobs" (43.4 \%) and "I do not 
think of working in the industry for longer years" (42.6 \%). Since the students agree with negative statements, it is obvious that students have some negative perceptions about the industry. These findings are coherent with previous studies.

Table 3. Perceptions of students who had an internship experience and those who had not concerning tourism industry

\begin{tabular}{|c|c|c|c|c|}
\hline \multirow[t]{2}{*}{$\begin{array}{c}\text { How much do you agree or disagree with each } \\
\text { statement? }\end{array}$} & \multicolumn{2}{|c|}{$\begin{array}{l}\text { Degree of agreement } \\
\text { or disagreement of } \\
\text { students who had an } \\
\text { internship experience }\end{array}$} & \multicolumn{2}{|c|}{$\begin{array}{l}\text { Degree of agreement or } \\
\text { disagreement of students } \\
\text { who did not have an } \\
\text { internship experience }\end{array}$} \\
\hline & Mean & $\begin{array}{l}\text { Standard } \\
\text { deviation }\end{array}$ & Mean & $\begin{array}{l}\text { Standard } \\
\text { deviation }\end{array}$ \\
\hline $\begin{array}{l}\text { 1. Participation of unskilled and non-educated } \\
\text { people in the industry diminishes job opportunities }\end{array}$ & 4.47 & .75 & 4.46 & .90 \\
\hline $\begin{array}{l}\text { 2. Bosses who are not educated or trained in tourism } \\
\text { prefer unskilled, low-paid employees for the purpose } \\
\text { of making much profit }\end{array}$ & 4.43 & .80 & 4.53 & .80 \\
\hline 3. Wage levels in the industry are insufficient & 4.11 & .91 & 4.01 & .96 \\
\hline 4. An internship is necessary to work in the industry & 4.10 & 1.06 & 4.29 & 1.00 \\
\hline 5. Working hours in tourism are very long and irregular & 4.06 & 1.01 & 4.07 & .99 \\
\hline 6. There is no job security in the industry & 4.05 & .89 & 3.94 & 1.14 \\
\hline $\begin{array}{l}\text { 7. Working conditions in the industry affects the } \\
\text { private life negatively }\end{array}$ & 3.98 & .99 & 3.71 & 1.14 \\
\hline $\begin{array}{l}\text { 8. A regular remuneration is difficult to gain because } \\
\text { of the seasonality of the industry }\end{array}$ & 3.92 & .98 & 3.92 & 1.04 \\
\hline 9. Owner/managers are not conscious about tourism & 3.92 & .92 & 3.85 & .93 \\
\hline $\begin{array}{l}\text { 10. Bosses who are unaware about the industry do not } \\
\text { want to employ educated and trained, quality personnel }\end{array}$ & 3.89 & .97 & 4.03 & 1.13 \\
\hline 11. Tourism graduates were not considered & 3.87 & 1.01 & 4.00 & 1.10 \\
\hline 12. Personnel in the industry are not appreciated much & 3.70 & .96 & 4.02 & .96 \\
\hline $\begin{array}{l}\text { 13. It is necessary to have a university degree to work } \\
\text { in the tourism industry }\end{array}$ & 3.70 & 1.30 & 4.11 & 1.24 \\
\hline 14. There is no future warranty in tourism & 3.61 & 1.24 & 3.46 & 1.39 \\
\hline 15. Career development in tourism is very slow & 3.53 & 1.07 & 3.36 & 1.14 \\
\hline 16. Career development in tourism is un-planned & 3.42 & 1.04 & 3.42 & 1.10 \\
\hline 17. I believe working in tourism suits me much & 3.34 & 1.17 & 3.61 & 1.17 \\
\hline $\begin{array}{l}\text { 18. Since un-planned structure of the industry } \\
\text { endangers the future of the industry, I do not } \\
\text { foresee a future for myself in this industry }\end{array}$ & 3.17 & 1.29 & 3.04 & 1.18 \\
\hline $\begin{array}{l}\text { 19. The advantages of working in the tourism } \\
\text { industry are much more than its disadvantages }\end{array}$ & 3.12 & .97 & 3.24 & 1.08 \\
\hline 20. There is gender discrimination in tourism & 3.01 & 1.18 & 3.04 & 1.31 \\
\hline 21. I do not think of working in the industry for many years & 2.84 & 1.32 & 2.68 & 1.28 \\
\hline 22. Promotional opportunities are satisfactory in tourism & 2.67 & .97 & 2.86 & .94 \\
\hline $\begin{array}{l}\text { 23. Tourism related jobs are more respected than } \\
\text { the other jobs }\end{array}$ & 2.61 & .92 & 2.74 & 1.00 \\
\hline $\begin{array}{l}\text { 24. I do not think that I would be patient and smile } \\
\text { to the tourists }\end{array}$ & 1.94 & 1.12 & 1.93 & 1.09 \\
\hline
\end{tabular}

Moreover, it is not surprising to find out that they plan to work in the industry since $68 \%$ of the respondents chose tourism education willingly. So, it can be said that, tourism students have been informed about conditions of sector before entering school. In the same manner, Kipkosgei et al., (2015) found that, majority of the student 
respondents at both undergraduate (62.24\%) and diploma (91.84\%) chose the tourism career willingly and informed. Zhang and $\mathrm{Wu}$ (2004), state that most students of vocational hospitality and tourism colleges in China know very little about hotels and sector before entering school and for most of them, this is a staggering experience when they find out more about hospitality and tourism operations. However, $42.6 \%$ of the respondents indicated that they would work in the industry for many years to come and, $30.7 \%$ of them "neither agree nor disagree" about this statement. This can be interpreted as they liked the business of tourism and they planned a career in the industry.

In order to see the differences between the students who had an internship experience and those who have not, the findings were divided into two sections in table 3 .

Table 4: Mann-Whitney Test

\begin{tabular}{|c|c|c|c|}
\hline & $\begin{array}{c}\text { Mann- } \\
\text { Whitney U }\end{array}$ & $\mathrm{Z}$ & $\begin{array}{l}\text { Significance } \\
(\mathrm{p})\end{array}$ \\
\hline $\begin{array}{l}\text { 1. Working conditions in the industry affects the private } \\
\text { life negatively }\end{array}$ & 4515,500 & $-1,686$ & ,092 \\
\hline 2. Tourism graduates were not considered & 4664,000 & $-1,321$ & 187 \\
\hline 3. Personnel in the industry are not appreciated much & 4204,000 & $-2,462$ &, 014 \\
\hline $\begin{array}{l}\text { 4. Bosses who are unaware about the industry do not want to } \\
\text { employ educated and trained, quality personnel }\end{array}$ & 4482,000 & $-1,523$ & ,128 \\
\hline $\begin{array}{l}\text { 5. Bosses who are not educated or trained in tourism prefer unskilled, } \\
\text { low-paid employees for the purpose of making much profit }\end{array}$ & 4627,000 & $-1,133$ & ,257 \\
\hline 6. Working hours in tourism are very long and irregular & 5173,500 &,- 040 & ,968 \\
\hline 7. Wage levels in the industry are insufficient & 4793,000 &,- 754 & ,451 \\
\hline 8. There is no job security in the industry & 5126,000 &,- 159 & ,874 \\
\hline 9. There is no future warranty in tourism & 4863,500 &,- 568 &, 570 \\
\hline 10. Owner/managers are not conscious about tourism & 4869,000 &,- 566 &, 571 \\
\hline 11. Career development in tourism is very slow & 4586,500 & $-1,149$ & ,251 \\
\hline 12. Career development in tourism is un-planned & 5023,500 &,- 042 & ,967 \\
\hline 13. There is gender discrimination in tourism & 4947,000 &,- 088 & ,930 \\
\hline $\begin{array}{l}\text { 14. Participation of unskilled and non-educated people in the } \\
\text { industry diminishes job opportunities }\end{array}$ & 4948,500 &,- 535 & 593 \\
\hline $\begin{array}{l}\text { 15. A regular remuneration is difficult to gain because of the } \\
\text { seasonality of the industry }\end{array}$ & 5105,500 &,- 089 & ,929 \\
\hline 16. I do not think that I would be patient and smile to the tourists & 5054,500 &,- 086 & ,931 \\
\hline 17. I do not think of working in the industry for many years & 4723,500 &,- 903 &, 367 \\
\hline $\begin{array}{l}\text { 18. Since un-planned structure of the industry endangers the future } \\
\text { of the industry, I do not foresee a future for myself in this industry }\end{array}$ & 4795,000 &,- 855 & ,392 \\
\hline 19. Promotional opportunities are satisfactory in tourism & 4471,000 & $-1,570$ & ,116 \\
\hline 20. Tourism related jobs are more respected than the other jobs & 4588,500 &,- 803 & ,422 \\
\hline $\begin{array}{l}\text { 21. The advantages of working in the tourism industry are much } \\
\text { more than its disadvantages }\end{array}$ & 4827,000 &,- 786 & ,432 \\
\hline 22. I believe working in tourism suits me much & 4376,000 & $-1,780$ &, $\mathbf{0 7 5}$ \\
\hline 23. An internship is necessary to work in the industry & 4526,500 & $-1,483$ & ,138 \\
\hline $\begin{array}{l}\text { 24. It is necessary to have a university degree to work in } \\
\text { the tourism industry }\end{array}$ & 4138,000 & $-\mathbf{2 , 5 4 8}$ &, $\mathbf{0 1 1}$ \\
\hline
\end{tabular}

When the responds of two groups are compared it is found that both groups' answers were similar. And most of these statements expressed were negative. Contrary to these findings; Barron and Maxwell (1993), Roney and Öztin (2007), Kozak and Kızllırmak (2001) found that perceptions of students who have an internship experience differ from those who have not, and they also found that their perceptions become negative after the internship experience. Datta et al., 2013 (cited in Kumar et al., 2014) also explained that there was 
difference in expectation between senior students who had completed internship and juniors who were yet to undergo industrial training. The students who had completed their training had a more negative perspective toward the hotel industry. It is also seen that both groups believe that they would be tolerant with tourists and work in the industry for longer years. Contrary to these evidences, King et al., (2003) found that approximately half of their Melbourne and Hong Kong tourism and hospitality graduate respondents never entered the industry or if they did, they left within a few years. However, Petrova and Mason (2004) claimed that in some countries (Mauritius, Australia and Turkey) students are interested in entering the industry, so these findings overlap their indication. Besides, they do not agree with promotion opportunities in tourism and respectability of the jobs in tourism. There appears to be no differences between the two groups related to these statements.

In order to find out any differences between the students who had an internship and not, Mann-Whitney test was conducted. Following hypotheses were proposed below:

Ho: The perceptions of both groups were not similar.

$\mathrm{H}_{1}$ : The perceptions of both groups were similar.

It is found that perceptions of both groups were not similar for two statements: Personnel in the industry are not appreciated much and It is necessary to have a university degree to work in the tourism industry. This difference is significant since $\mathrm{p}<\alpha=0,05$. Here, the difference in the perceptions of both groups about the necessity of university education can be explained by the fact that students trust level in the educational institutions drops after the internship experience. It is also found that perceptions of both groups were not similar for other two statements: Working conditions in the industry affects the private life negatively and I believe working in tourism suits me much. This difference is significant since $\mathrm{p}<\alpha=0,1$. This may be explained by the lack of experience in the industry.

For other statements, it is found that there were no significant differences between the perceptions of students who had an internship experience with those who had not. Accordingly, the second hypothesis is accepted.

\section{CONCLUSION}

This study focuses on analysing any differences between the industry perceptions of students who had an internship experience with those who had not. The study results indicate that the prospective employees have negative perceptions on the industry. Moreover, it is found that there are no significant differences in the perceptions of students who had an internship with those who had not. The negative perceptions can be explained by the insufficient human resources practices in the industry and negative attitudes against the internship students. All-inclusive pricing and price competition experienced in hotels in Turkey resulted in a decrease in the quality of the visitors and diminished quality expectations of the travellers. Accordingly, the owner/managers neglect the quality issue. As a result, human resources practices and policies are not appreciated by most of the companies. These businesses prefer to employ low-skilled and low-paid workers rather than recruiting qualified personnel and investing in human resources. This is why most of the students believe that the employment of people who are not educated in tourism diminishes their job opportunities. Although the perceptions of the students are negative, both groups of students with internship experience and the others think that they would be pleasant and gracious. Besides, majority of students plan to work longer years in the tourism industry. It could be stated that willingness to choose tourism education results in students' desire to work in the industry. Although there are some weaknesses of the industry, students' willingness to work in tourism is important for the industry. It is a known fact that the industry is in need of young, dynamic and qualified work force. For these reasons, educational institutions, public and private associations 
should take the responsibility and pay extra efforts lest graduates leave the industry or lose their motivation at work. Educational institutions may help students to change their negative perceptions. Besides, these institutions can inform the students on the nature of working conditions and can motivate students by creating awareness about the tourism and hospitality sector. Tourism education institutions should design the course curriculum and job description to provide job opportunities that favourable and express positive perception of students' towards hotel and tourism industry in the future. Also, they ought to provide education programs which would increase the qualifications of the graduates according to the industry needs. Increase in the quality of education would result in an increase in the quality of students, consequently the quality of employees. It is crucial to close the gap between what is taught to students and what the industry expects of the students being hired. Tourism businesses should also take the responsibility in overcoming the negative perceptions of the students. They should: improve their human resources practices and policies; maintain better working conditions; better understand the needs of internship students; pay attention to employ tourism educated personnel.

\section{REFERENCES}

Airey, D., Frontistis, A., (1997), Attitudes to Careers in Tourism: An Anglo Greek Comparison, Tourism Management, 18(3), 149-158, Elsevier, York, UK.

Airey, D., (2005), Growth and Development, In Airey, D. and Tribe, J., ed., An International Handbook of Tourism Education, Ch.2, Elsevier Ltd., Surrey.

Airey, D., (2016), Tourism Education: Past, Present and Future, The Business of Tourism, 17, 9-12.

Akıncı, Z., (2016), What Kind of Tourism Education Must the School Offer?, Journal of Tourism \& Hospitality, 5(3), DOI: 10.4172/2167-0269.1000212, OMICS.

Akıncı, Z., Yurcu, G., Kasalak, M., A., (2017), Factors Affecting Educational Motivation in University: A Study of Tourism Education in Antalya, Journal of Human Sciences, 14(2), 1983-2000, Open Journal, Sakarya University, Sakarya, Turkey.

Aksu, A., A., Köksal, C., D., (2005), Perceptions and Attitudes of Tourism Students in Turkey, International Journal of Contemporary Hospitality Management, 17(4/5), 436-447, Emerald Publishing Limited, Bingley, UK.

Anandhwanlert, T., Wattanasan, C., (2016), Career Perception of Undergraduate Students on Tourism and Hospitality Industry in Thailand, Global Advanced Research Journal of Management and Business Studies, 5(10), 339-346.

Austin, M., J., Rust, D., Z., (2015), Developing an Experiential Learning Program: Milestones and Challenges, International Journal of Teaching and Learning in Higher Education, 27(1), 143-153.

Ayres, H., (2006), Education and Opportunity as Influences on Career Development: Findings from a Preliminary Study in Eastern Australian Tourism, Journal of Hospitality, Leisure, Sport \& Tourism Education, 5(1), 16-28, Elsevier, York, UK.

Barron, P., Maxwell, G., (1993), Hospitality Management Students' Image of the Hospitality Industry, International Journal of Contemporary Hospitality Management, 5(5), 5-8, Emerald Publishing Limited, Bingley, UK.

Başaran, K., (2016), Experiential Learning in Tourism Education in the North Cyprus, Academic Dissertation, The Board of the School of Education of the University of Tampere, Tampere University Press, Finland.

Birdir, B., (2002), Turizm ve Otel Işletmeciliği Ĕ̆itimi Alan Lisans Öğrencilerinin Turizm Endüstrisinde Çalışmayı Tercih Etmemelerinin Temel Nedenleri: Bir Nominal Grup Tekniği Araştırması, In Ministry of Tourism, ed. Proceedings of The Conference and Workshop on Tourism Education, 495504, Ministry of Tourism Pres, Ankara.

Blomme, R., Van Rheede, A., Tromp, D., (2009), The Hospitality Industry: An Attractive Employer? An Exploration of Students' and Industry Workers' Perceptions of Hospitality as a Career Field, Journal of Hospitality \& Tourism Education, 21(2), 6-14, Taylor \& Francis Group, UK.

Boylu, Y., (2002), Türkiye'deki Örgün Turizm Eğitiminin Sistematik Olmayan Bir Açıdan Değerlendirilmesi, DAÜ Turizm Araştırmaları Dergisi, 3(2), 63-78, Doğu Akdeniz Üniversitesi Matbaası, Kuzey Kıbrıs.

Brown, E., A., Arendt, S., W., Bosselman, R., H., (2014), Hospitality Management Graduates'Perceptions of Career Factor Importance and Career Factor Experience, International Journal of Hospitality Management, 37, 58-90, Elsevier, York, UK.

Busby, G., (2003), Tourism Degree Internships: A Longitudinal Study, Journal of Vocational Education and Training, 55(3), 319-334, Taylor \& Francis Group, UK.

Casado, M., A., (1992), Student Expectations of Hospitality Jobs, The Cornell Hotel and Restaurant Administration Quarterly, 33(4), 80-82, Elsevier, York, UK. 
Christou, E., S., (1999), Hospitality Management Education in Greece an Exploratory Study, Tourism Management, 20(6), 683-691, Elsevier, York, UK.

Christou, E., Sigala, M., (2002), Conference Report: Innovation in Hospitality and Tourism Education, International Journal of Tourism Research, 4, 65-67, John Wiley \& Sons Ltd, NJ, USA.

Çakar, K., Çizel, B., (2015), The Higher Education System in the Field of Hospitality \& Tourism Management: A Comparative Analysis between Turkey, Switzerland and Germany, Mediterranean Journal of Humanities, 2, 165-177, Akdeniz University, Faculty of Letters, Antalya.

Datta, A., Biswakarma, K., S., Nayak, B., (2013), Effect of Internship on Career Perception of Hotel Management Students, Zenith International Journal of Multidisciplinary Research, 3(10), 50-63 cited in Kumar, A., Kumar Singh, P., Kumar, A. and Dahiya, S., (2014), Changing Perception of Students toward Hospitality Industry: A Comparative Analysis, International Journal of Tourism \& Hospitality Review (IJTHR), 1(1), 7-12, Online, ISSN : 2395-7654.

Downey, J., F., De Veau, L., (1988), Hospitality Internships: An Industry View, The Cornell Hotel and Restaurant Administration Quarterly, 29(3), 18-20, Elsevier, York, UK.

Garavan, T., N., Morley, M., (1997), The Socialization of High-Potential Graduates into the Organization, Journal of Managerial Psychology, 12(2), 118-137, Emerald Group Publishing Ltd., Bingley, UK.

Getz, D., (1994), Students' Work Experiences, Perceptions and Attitudes towards Careers in Hospitality and Tourism: A Longitudinal Case Study in Spey Valley, Scotland, International Journal of Hospitality Management, 13(1), 25-37, Elsevier, York, UK.

Goodman, R., J., Sprague, L., G., (1991), The Future of Hospitality Education: Meeting the Industry's Needs, The Cornell Hotel and Restaurant Administration Quarterly, 32(2), 66-69, Elsevier, York, UK.

Grobelna, A., (2017), The Perception of Job-related Motivators When Choosing a Career in the Tourism and Hospitality Industry - A Comparative Study Between Polish and Spanish Students, International Journal of Management and Economics, 53(2), 84-106, Online, ISSN: 2299-9701.

Hawkins, D., E., (2006), Transferring Tourism Knowledge: The Role of Higher Education Institutions, Journal of Quality Assurance in Hospitality \& Tourism, 7(1/2), 13-27, Taylor \& Francis Group, UK.

Heskett, J., L., Jones, T., O., Loveman, G., W., Sasser, W., E., Schlesinger, L., A., (1994), Putting the Service-Profit Chain to Work, Harvard Business Review, 72(2), 164-170, Harvard Business Publishing, Brighton.

Jafari, J., (1990), Research and Scholarship: the Basis of Tourism Education, Journal of Tourism Studies, 1(1), 33-41, James Cook University, Australia.

Jafari, J., (1997), Tourismification of the Profession. Chameleon Job Names Across the Industry, In: WTO, Human Capital in the Tourism Industry of the 21st Century, 202-214, WTO, Madrid, cited in Munar, A. M., (2007), Is the Bologna Process Globalizing Tourism Education?, Journal of Hospitality, Leisure, Sport \& Tourism Education, 6(2), 68-82, Elsevier, York, UK.

Jameson-Charles, M., (2012), Tourism Education from A Relationship Management Perspective, Caribbean Curriculum, 19, 145-170, The University of the West Indies, School of Education, St Augustine.

Jenkins, C., I., (1997), Tourism Educational Systems, İnstitutions And Curricula: Standardization and Certification in Human Capital, in: WTO, The Tourism Industry of the 21st Century, 215-222, WTO, Madrid, cited in Munar, A. M., (2007), Is the Bologna Process Globalizing Tourism Education?, Journal of Hospitality, Leisure, Sport \& Tourism Education, 6(2), 68-82, Elsevier, York, UK.

Jenkins, A., K., (2001), Making a Career of It? Hospitality Students' Future Perspectives: An Anglo-Dutch Study, International Journal of Contemporary Hospitality Management, 13(1), 13-20, Emerald Publishing Limited, Bingley, UK.

Kelley-Patterson, D., George, C., (2001), Securing Graduate Commitment: An Exploration of the Comparative Expectations of Placement Students, Graduate Recruits and Human Resource Managers within the Hospitality, Leisure and Tourism Industries, Hospitality Management, 20, 311-323, Elsevier, York, UK.

Kim, J., H., G., (2008), Career Expectations and Requirements of Undergraduate Hospitality Students and the Hospitality Industry: An Analysis of Differences, Master Thesis, AUT University School of Hospitality and Tourism, New Zealand.

King, B., McKercher, B., Waryszak, R., (2003), A Comparative Study of Hospitality and Tourism Graduates in Australia and Hong Kong, International Journal of Tourism Research, 5(6), 409-420, John Wiley \& Sons Ltd, NJ, USA.

Kipkosgei, B., Kivuva, A., K., Muiruri, J., N., (2015), Perceptions of Tourism Students Towards Career Choice in the Kenyan Tourism Industry: A Comparative Study of Moi University and Kenya Utalii College, African Journal of Tourism, Hospitality and Leisure Studies, 1(2), Online, http://onlinesciencejournals.com/index.php/ajthls.

Ko, W., H., (2008), Training, Satisfaction with Internship Programs, and Confidence about Future Careers among Hospitality Students: A Case Study of Universities in Taiwan, Journal of Teaching in Travel \& Tourism, 7(4), 1-15, The Haworth Press.

Kozak, M., Kızılırmak, İ., (2001), Türkiye’de Meslek Yüksekokulu Turizm-Otelcilik Programı Öğrencilerinin Turizm Sektörüne Yönelik Tutumlarının Demografik Değişkenlere Göre Değişimi, Anatolia: Turizm Araştırmaları Dergisi, 12, 9-16, Detay Yayıncılık, Ankara.

Kusluvan, S., Kusluvan, Z., (2000), Perceptions and Attitudes of Undergraduate Tourism Students towards Working in the Tourism Industry in Turkey, Tourism Management, 21(3), 251-269, Elsevier, York, UK. 
Lee, M., H., Lu, H., T., Jiao, Y., H., Yeh, P., H., (2006), Research on Correlations Between Off-School Internship Systems and Work Performances in Hospitality and Tourism Education, Journal of Teaching in Travel \& Tourism, 6(3), 69-87, The Haworth Press, Inc., London.

Leiper, N., (1999), A Conceptual Analysis of Tourism-Supported Employment Which Reduces the Incidence of Exaggerated, Misleading Statistics about Jobs, Tourism Management, 20 (5), 605-613, Elsevier, York, UK.

Malihah, E., Diyah Setiyorini, H., P., (2014), Tourism Education and Edu-Tourism Development: Sustainable Tourism Development Perspective in Education, The 1st International Seminar on Tourism (ISOT), EcoResort and Destination Sustainability: Planning, Impact, and Development, 27 - 28 October, Bandung.

Menemenci Bahcelerli, N., Sucuoglu, E., (2015), Undergraduate Tourism Students' Opinions Regarding the Work Conditions in the Tourism Industry, Procedia Economics and Finance, 26, 1130 - 1135, Elsevier, York, UK.

Munar, A., M., (2007), Is the Bologna Process Globalizing Tourism Education?, Journal of Hospitality, Leisure, Sport \& Tourism Education, 6(2), 68-82, Elsevier, York, UK.

Nolan, C., (2002), Human Resource Development in the Irish Hotel Industry: The Case of the Small Firm, Journal of European Industrial Training, 26 (2/4), 88-99, Emerald Group Publishing Ltd., Bingley, UK.

O'Leary, S., Deegan, J., (2005), Career Progression of Irish Tourism and Hospitality Management Graduates, International Journal of Contemporary Hospitality Management, 17(4/5), 421-432, Emerald Publishing Limited, Bingley, UK.

O'Mahony, G., B., Sillitoe, J., F., (2001), Identifying the Perceived Barriers to Participation in Tertiary Education among Hospitality Employees, International Journal of Contemporary Hospitality Management, 13(1), 21-29, Emerald Publishing Limited, Bingley, UK.

Okumus, F., Yagci, O., (2005), Tourism Higher Education in Turkey, Journal of Teaching in Travel \& Tourism, 5(1/2), 89-116, The Haworth Press, Inc., London.

Padurean, L., Maggi, R., (2014), TEFI Values in Tourism Education: A Comparative Analysis, in Prebezac, D., Schott, C. and Sheldon, P. J., ed., The Tourism Education Futures Initiative, Ch.8 Routledge, Oxon.

Pavesic, D., V., Brymer, R., A., (1990), Job Satisfaction: What's Happening to the Young Managers?, The Cornell Hotel and Restaurant Administration Quarterly, 30(4), 90-96, Elsevier, York, UK.

Peters, M., (2005), Entrepreneurial Skills in Leadership and Human Resource Management Evaluated by Apprentices in Small Tourism Businesses, Education and Training, 47(8/9), 575-591, Emerald Publishing Limited, Bingley, UK.

Petrova, P., Mason, P., (2004), The Value of Tourism Degrees: A Luton-Based Case Study, Education and Training, 46(3), 153-161, Emerald Publishing Limited, Bingley, UK.

Pizam, A., Tesone, D., V., (2005), The Utilization of Human Resources in Tourism SMEs: A Comparison Between Mexico and Central Florida, in Jones, E. and Haven-Tang, C., ed., Service Quality and Destination Competitiveness, Ch.14, CABI Publishing, Cambridge.

Purcell, K., Quinn, J., (1996), Exploring the Education-Employment Equation in Hospitality Management: A Comparison of Graduates and Hnds, International Journal of Hospitality Management, 15(1), 51-68, Elsevier, York, UK.

Richardson, S., (2008), Undergraduate Tourism and Hospitality Students Attitudes Toward a Career in the Industry: A Preliminary Investigation, Journal of Teaching in Travel \& Tourism, 8(1), 23-46, Taylor \& Francis Group, UK.

Roney, S., A., Öztin, P., (2007), Career Perceptions of Undergraduate Tourism Students: A Case Study in Turkey, Journal of Hospitality, Leisure, Sport \& Tourism Education, 6(1), 4-17, Elsevier, York, UK.

Ross, G., F., (1994), What Do Australian School Leavers Want of the Industry?, Tourism Management, 15(1), 62-66, Elsevier, York, UK.

Sibanyoni, J., J., Kleynhans, I., C., Vibetti, S., P., (2015), South African Hospitality Graduates’ Perceptions of Employment in The Hospitality Industry, African Journal of Hospitality, Tourism and Leisure, 4(1), ISSN: 2223-814X, Online @ http//: www.ajhtl.com.

Stutts, A., T., (1995), Viewpoint: Higher Education in Hospitality Management, International Journal of Contemporary Hospitality Management, 7(6), 52-53, Emerald Publishing Limited, Bingley, UK.

Tas, R., (1988), Teaching Future Managers, The Cornell Hotel and Restaurant Administration Quarterly, 29(2), 58-64, Elsevier, York, UK.

Wellings, C., Bibbings, L., (2004), Perceptions and Expectations of $1^{\text {st }}$ Year Students Studying Tourism in Higher Education, In ATHE, (Association for Tourism in Higher Education) Critical Issues in Tourism Education, Missenden Abbey, Buckinghamshire, UK 1-3 December 2004, Higher Education Academy Network for Hospitality, Leisure, Sport and Tourism: UK.

Yllmazdogan, O., C., Secilmis, C., Cicek, D., (2015), The Effect of Corporate Social Responsibility (CSR) Perception on Tourism Students' Intention to Work in Sector, Procedia Economics and Finance, 23, 1340 - 1346, Elsevier, York, UK.

Zhang, H., Q., Wu, E., (2004), Human Resources Issues Facing the Hotel and Travel Industry in China, International Journal of Contemporary Hospitality Management, 16(7), 424-428, Emerald Publishing Limited, Bingley, UK.

Submitted:

02.04.2017
Revised:

23.03.2018
Accepted and published online 27.03.2018 